\title{
Allegation of insider dealing
}

\section{Washington}

GENENTECH, the leading US biotechnology company, disclosed last week that the Securities and Exchange Commission (SEC) was investigating a possible case of insider trading that took place before the announcement, on 2 February, of the company's proposed $\$ 2,100$ million merger with healthcare conglomerate, Roche Holdings (see Nature 343, 495; 1990).

The SEC inquiry, sparked off by an unusually high volume of trading in Genentech securities on the Pacific Stock Exchange just before details of the merger were made public, focuses on the wife of G. Kirk Raab, the company's president and chief executive officer. In particular, it concerns certain 'communications' between Molly Raab and a member of her family, and on subsequent trading in Genentech securities by persons other than herself.

In a short statement issued by the company, Genentech makes it clear that it believes that neither it nor Mr Raab is the subject of any investigation and that $\mathrm{Mr}$ Raab exercised proper care in maintaining the confidentiality of the merger information. Mr and Mrs Raab, who are said to be cooperating fully with the investigation, would not comment while the inquiry is in process.

Brief mention of the inquiry was made in the detailed proxy statement outlining the merger agreement, which was sent to shareholders last week. Shareholders will be asked to vote on the proposed merger with Roche at an annual meeting of stockholders, postponed since April, and now due to be held on 8 June. Stock analyst Stuart Weisbrod believes this inquiry "is not going to affect the deal [merger] at all".

Interestingly, the proxy statement reveals that although Roche will have only two members on a 13-member board of directors, it will wield somewhat more influence over Genentech's business transactions than was originally anticipated. Roche is to have the power of veto over acquisitions or the sale of assets and over the issuing or repurchase of the company's securities. In addition, Genentech cannot enter into licensing agreements with respect to its products or technologies without offering Roche first refusal.

Weisbrod notes that the "unusually high" severance awards - so called 'golden parachute awards' - payable to the top six Genentech officials should they lose their jobs as a result of the merger, would be "the only thing that shareholders at the meeting can question". Under these agreements, chairman Robert A. Swanson and Raab would receive payments of $\$ 6.3$ million and $\$ 6.6$ million respectively.
When asked whether such lump sum severance awards equal to five times the employee's salary and bonus were unusually high, Genentech spokesperson Susan Rogers said that these people "have put their positions on the line" and that these separate agreements are intended

\section{BIOTECHNOLOGY}

\section{Little apparent interest in Celltech sell-off}

\section{London}

A BUY-OUT of Celltech, Britain's largest biotechnology company, by a large pharmaceuticals company now seems unlikely. The possibility emerged last autumn, when British and Commonwealth Holdings (B\&C), decided to sell its majority 36.4 per cent stake, providing a golden opportunity for a takeover attempt (see Nature 342, 334, 23 November 1989). But John Jackson, Celltech's chairman, last week confirmed that an announcement that the company is looking for a new chief executive means that no single buyer has emerged and the B\&C shares are likely to go to smaller investors.

A German or Japanese buy-out of Celltech was expected by some analysts, a possibility that provoked alarm in the United Kingdom. Labour opposition leader Neil Kinnock, speaking to the Parliamentary and Scientific Committee in February, criticized the proposed sale, because of Celltech's involvement with the governmentfunded UK Medical Research Council. The company has a 'memorandum of understanding' with the council to exchange research information.

Other analysts are not surprised by the turn of events. Although Celltech's expertise in monoclonal antibody technology might be of interest, Celltech has not yet matured financially into a ripe takeover target, they say. The company was formed in 1980, and recorded its first profitable year in 1987.

Mark Dodgson, from the University of Sussex, who has spent a year studying Celltech, describes the company's predicament as "a tragedy". He says that Celltech's expensive research and development programme relies on long-term investment. B\&C's withdrawal means that Celltech has to look to a venture capital market for finance which tends to view investments on their short-term merit.

B\&C's Celltech shares may even end up being disposed of by an official receiver, because liquidation of $B \& C$ is now a possibility. The company is reeling following the collapse of Atlantic Computers, B\&C's computer leasing subsidiary.

Peter Aldhous "to protect them personally in the event of any adverse consequences".

Even if shareholders approve the merger in June, the effective date of merger could be delayed if at that time clearance by the Federal Trade Commission has not been given. Genentech and Roche have still to satisfy the Hart-ScottRodino Antitrust Improvements Act.

Dlane Gershon

\section{ARCTIC RESEARCH \\ Arctic cooperation}

\section{Boston}

A DRAMATIC increase in the number of cooperative international agreements governing Arctic research and affairs is documented in a report released by a presidential advisory group the US Arctic Research Commission. The report cites some 450 active governmental and scientific agreements worldwide that pertain to the region, more than half of which have been reached within the past decade, suggesting that Arctic research is beginning to garner the kind of politically active global scientific constituency that Antarctic research has enjoyed for some time.

The surge in international arrangements is partly due to increasing interest in research on global environmental change; the environmentally sensitive Arctic region may provide important early indications of global climate change, atmospheric pollution and greenhouse warming. The role of the Arctic Ocean in global change processes is coming under particular scrutiny - it is known to influence the deep water of the North Atlantic, one of the dominant water masses in the earth's oceans. The Arctic Ocean is thought also to play a disproportionately significant role in the removal of biogenic and human-made materials from the atmosphere and is an important "heat sink" for the global atmospheric system. But, Arctic researchers say, we know less about the Arctic Ocean than any other ocean in the world.

The report also highlights an increase in the number of cooperations with the Soviet Union. Soviet willingness to participate in international efforts, especially those concerning its vast territorial holdings in the East Arctic, has helped to account for what the report terms a "geometric" increase in international cooperative agreements in the region. Soviet interest has not been limited to research on global change: recent bilateral and multilateral agreements govern everything from the protection of polar bears to contingency plans for oil spills or radioactive accidents in the region.

Seth Shulman

"Preliminary International Agreements for Research. Logistics and Access Concerning the Arctic", is pub lished by the U.S. Arctic Research Commission, Washington, DC, April 1990 